\title{
Professors and Experts: Would You Like Your Articles to be Read?
}

\author{
Catherine Buday (EIX) \\ James C Wetherbe (Texas Tech University)
}

\author{
KEYWORDS: Research Methods, Teaching Methods, \\ Research.
}

An old joke says that if a doctoral student put a $\$ 100$ bill in his or her dissertation paper that was filed away in the university library, ten years later the $\$ 100$ bill would still be there.

Did you know that $50 \%$ of articles written by academics are never cited, which indicates how little they are read? Entrepreneurship scholars, professors and researchers must unearth new truths about their subjects and prove in their research papers that they used rigorous methods to do so. But too often, the papers that result from this rigor are dry, difficult to understand and maybe at best interesting only to other academics.

Yet so much research, whether primary or secondary, yields important insights that deserve more attention, and that actually help practicing entrepreneurs be more successful. The challenge is identifying those insights and then presenting them in a way that people who are not academics, consultants or other specialists can understand and use right away.

This is a key part of what we do at EIX.org and familybusiness.org(https://familybusiness.org). Over the years we have published dozens of "research translation" articles that distill the key takeaways from research papers and show why they are important to people who run businesses. In addition to helping practicing entrepreneurs, these articles also give greater visibility and recognition to the individuals and teams who did the research. And for professors who must prove they are having an impact through their work, being able to show an article that has thousands of page views is a plus. Many of our authors have achieved that.

\section{A Different Way to Write}

But getting these benefits requires a different type of writing, and putting one's self in the shoes of the people who need the information. How can a professor or

consultant do that? First, they should focus on the big picture: addressing important, real problems or questions faced by everyday entrepreneurs. That alone will get their attention. Then, along with laying out the problem or question, the article can describe specific solutions and show how your research proved they work.

The following template is a useful framework for organizing your article. See if you can answer these questions as simply as possible, using non-academic language:

- What problem did you set out to solve and why did you choose this problem?

- What did you think you'd find out? (hypothesis)

- What did your study, such as a survey, measure? (describe the types of data or survey respondents, where you found them, how many were measured, and the questions or factors you explored).

- What were the key things you discovered from your research? Were you surprised?

- What can business owners or startup founders learn from your research that will help them be more successful? And, relatedly:

- Based on your research, what should a startup, entrepreneur-led venture or family business be implementing or doing differently? What would they find most surprising about your study results?

\section{Organizing Your Article}

Once you've answered these key questions, you will have the core message of your article, which can then be organized into a simple, straightforward problem/solution and/or question/answer format. For example, these EIX articles have achieved exceptional 
views: more than 100,000 for the first one, and more than 70,000 for the second.

How to Care for Your Team During a Crisis (https://eiexchange.com/content/how-to-care-for-yourteam-during-a-crisis)

Which Innovations Should You Keep After the Crisis is Over?(https://eiexchange.com/content/whichinnovations-should-you-keep-when-the-crisis-is-over)

Both of these articles use a question or promise an answer in the title to attract the reader. Note that each of articles introduces a problem first, and then provides several solutions, following this structure:

- Problem

- Solution a

- Solution b

- Solution c

- Etc.

Of course, an article can present several problems/questions that have only one solution or multiple solutions.

It is all about clarity. In organizing your key pieces of advice, you might find it better to pair each problem with a solution. Consider the following article that introduces EIX.org as a new publication:

EIX: Reducing Cycle Time in Thought Leadership (https://eiexchange.com/content/3-eix-reducing-cycletime-in-thought-leadership)

Here's an excerpt from that article that illustrates how to pair up problems with solutions in an itemized way:

Other innovations of EIX include:

1. Traditional journal page limitation no longer applies, since the web allows for instant publication of more articles, whatever the length. This means EIX can publish more articles and more variety-research, practitioner, educational, case studies, commentaries and entrepreneurial proposals.

2. One-way communication -- traditional printed journals are replaced with online blogs allowing comments and debate among authors and readers, leading to scoring and ranking of articles.
3. Limited access to traditional print journals is resolved by sharing online links to articles and references, including social media links.

4. To overcome the "too many articles and not enough time" challenge for the public audience, EIX will use "crowdsourcing" to identify the most read and liked articles on different topics. Also, participants in the EIX platform can specify their topics of interest and be alerted via email or text when a new article or video of interest is published.

5. To overcome the perceived prestige advantage of print journals, authors of top-ranked EIX articles will be granted Schulze Award Scholarships to award to students of the authors' choice. Authors will be invited to present at an annual EIX conference held at the Schulze School of Entrepreneurship.

6. Beyond printed articles of traditional journals, EIX will have videos of thought-leading interviews, speeches, courses and company stories as well as entrepreneurial proposals from students and practitioners.

\section{Take a Cue from Super Bowl Ads}

It is a simple straightforward discipline to be clear when you are discussing a problem or a solution (question or an answer). It allows research to be more expressive. This construct is so powerful it is used in the majority of the most expensive messages on earth: advertising, especially Super Bowl ads! Most ads use a problem or a question as a hook to get our attention, and then quickly follow with a solution.

Once you organize your problem/question and follow with your solution/answers, what's left is to give your article some pizazz, with an intriguing title and first paragraph that engages the reader right away by presenting a compelling problem or question that engages them. It should be a style that might be right at home on the business or science page of a big-city newspaper or website. Our staff can help you with that if you're stumped.

For inspiration, check out these articles from noted academics about their research and what it means for entrepreneurs:

Being Female Affects Business Loans from Family Members and Friends 
(https://familybusiness.org/content/being-female-affectsbusiness-loans-from-family)

Crowdfunded Ventures: Where Angels Dare to Tread (https://eiexchange.com/content/393-crowdfundedventures-where-angels-dare-to-tread)

'Home Field Advantage' Works in Business as Well as Baseball(https://eiexchange.com/content/259-homefield-advantage-works-in-business-as-well-a)

When Entrepreneurs Have Trouble With Monogamy (https://familybusiness.org/content/when-entrepreneurshave-trouble-with-monogamy-it)

\section{Businesses Named After Founders Enjoy Greater Returns \\ (https://eiexchange.com/content/395-businesses- named-after-founders-enjoy-greater-re)}

Too Much Love in the Family Can Hurt (https://familybusiness.org/content/Too-much-love-inthe-family-can-hurt)

The Fredo Factor: How Deadbeats and Troublemakers Hurt Family Business (https://familybusiness.org/content/the-fredo-factor-howdeadbeats-and-troublemakers) 